\title{
PENINGKATAN HASIL BELAJAR IPS MELALUI PENGGUNAAN MEDIA GAMBAR PADA SISWA KELAS III SDN 50 BULU' DATU PALOPO
}

\author{
Dahlia \\ Institut Agama Islam Negeri Palopo \\ Jl. Agatis Balandai Kota Palopo 91914 \\ E-mail: dahliapgmi.a@yahoo.com
}

\begin{abstract}
The main problem in this study is the low learning outcomes of social studies for III grade students of SDN 50 Bulu' Datu Palopo. There is also the problem formulation, that is : can the purpose of this study is that student learning outcomes can be improved by using picture media in class III SDN 50 Bulu' DATU Palopo on subject IPS. held three times, with the planning stage act of observation and reflection. The subject of this research is class students III SDN 50 Bulu' Datu Palopoin odd semester of schoolyear 2018/2019 with a total of 23 students. The results of the show that : with the use of media images off class III SDN 50 Bulu' Datu Palopo students' learning outcomes conducted in two cycles shows that student learning outcomes have increased,from the cycle I average value 72 with percentage of completeness $65 \%$, while cycle II average value 92 with percentage of complete $100 \%$ and has fulfilled the value KKM that is 70.
\end{abstract}

Keywords: learning outcomes,student, image media

\begin{abstract}
Abstrak
Pokok permasalahan dalam penelitian ini adalah rendahnya hasil belajar IPS pada siswa kelas III SDN 50 Bulu' Datu Palopo. Tujuan penelitian ini adalah Hasil belajar siswa dapat ditingkatkan dengan menggunakkan media gambar di kelas III SDN 50 Bulu' Datu Palopo pada mata pelajaran IPS.Penelitian ini merupakan penelitian tindakan kelas (PTK) yang terdiri dari dua siklus, masing-masing siklus dilaksanakan sebanyak 3 kali pertemuan, dengan tahapan Perencanaan, Tindakan, Observasi, dan Refleksi. Subjek penelitian ini adalah siswa kelas III SDN 50 Bulu' Datu Palopo pada semester ganjil tahun pelajaran 2018/2019 dengan jumlah siswa 23 orang. Hasil penelitian menunjukkan bahwa: dengan diterapkan penggunaan media gambar hasil belajar siswa setiap siklusnya mengalami peningkatan. Berdasarkan tes hasil belajar siswa kelas III SDN 50 Bulu' Datu Palopo yang dilakukan sebanyak dua siklus menunjukkan bahwa hasil belajar siswa mengalami peningkatan, dari siklus I nilai rata-ratanya 72 dengan persentase ketuntasan 65\%, sedangkan siklus II nilai rata-ratanya 92 dengan persentase 100\% dan sudah memenuhi nilai KKM yaitu 70.
\end{abstract}

Kata Kunci,: Hasil Belajar, Siswa, Media Gambar

\section{PENDAHULUAN}

Pendidikan merupakan suatu kegiatan yang dilakukan agar dapat mengembangkan kemampuan manusia dalam dirinya baik pembawaan 


\section{0 | Dahlia}

jasmani maupun rohani sesuai dengan nilai-nilai yang ada di dalam masyarakat. Dalam kegiatan pendidikan siswa menjadi unsur yang penting dalam proses pembelajaran. (Fuad Ihsan, 2015:1). Pendidikan berfungsi membantu karasteristik pribadinya kearah positif,yang memjadikan siswa lebih baik di suatu lingkungannya. Menurut (Sudarwan Danim, 2011 : 41) Sebagaimana dalam UU NO. 20 Tahun 2003 tentang sikdiknas. Di dalam UU ini disebutkan bahwa pendidikan bertujuan untuk berkembangnya potensi siswa agar menjadi manusia yang beriman dan bertakwa kepada Tuhan yang maha esa, berakhlak mulia, sehat, berilmu, cakap, kreatif, mandiri dan menjadi warga negara yang demokratis serta bertanggung jawab (Nana Syaodih Sukmadinata, 2009: 4 ).

Pengajar dalam dunia pendidikan harus mampu membuat siswa kreatif dan inovatif dalam membentuk pola pikir siswa di dalam pembelajaran. Hal ini sesuai dengan kajian teori yang dikemukakan oleh (Rustan, 2001) yaitu "dalam konteks pendidikan multikultural yang berkarakter, pengajar harus mampu memberikan contoh-contoh pengaplikasian nilai dan tingkah laku kesehariannya. Pengaplikasian nilai-nilai budaya diharapkan mampu mencegah timbulnya degradasi sosial dalam tatanan masyarakat akibat globalisasi.

Pembelajaran adalah proses terjadinya interaksi antara pendidik dan siswa serta sumber belajar dan media yang digunakan, dalam upaya terjadinya perubahan pada aspek kognitif, afektif dan motorik. Oleh karena itu agar aktivitas pembelajaran bermakna bagi siswa, pendidik perlu mengembangkan media pembelajaran yang bervariasi dan menarik bagi siswa. Pembelajaran merupakan terjemahan dari kata "intruction" yang dalam bahasa yunani disebut instructus atau "intruere" yang berarti menyampaikan pikiran, dengan demikian arti instruksional adalah menyampaikan pikiran atau ide yang telah diolah secara bermakna melalui pembelajaran (Bambang \& Warsita 2008 : 265). Pembelajaran adalah proses komunikasi antara pembelajar, pengajar, dan bahan ajar. Bentuk komunikasi tidak akan berjalan tanpa adanya bantuan sarana untuk menyampakan pesan.

Belajar adalah perubahan tingkah laku siswa setelah melakukan suatu tindakan dengan menggunakan media yang dapat membantu proses pembelajaran (Hujair AH Sanakay, 2009 : 3). Pengertian secara psikologis belajar merupakan suatu proses perubahan yaitu perubahan tingkah laku sebagai hasil dari interaksi dengan lingkungannya dalam memenuhi lingkungan hidupnya (Slameto 2015 : 2). Belajar adalah merupakan tindakan dan perilaku yang kompleks, sebagai tindakan belajar hanya dialami oleh siswa itu sendiri Menurut Dimyanti \& Mudjiono dalam (Syaiful Sagala, 2008:

PiJIES: Pedagogik Journal of Islamic Elementary School 
13). Belajar merupakan perubahan dalam kepribadian, yang didapatkan siswa setelah melakukan suatu proses pembelajaran yang dapat dilihat dari hasil belajarnya, menurut Witherington dalam (Sukmadinata, 2009 : 155). Agar dapat diperoleh hasil pembelajaran yang optimal diperlukan kemampuan guru mengenai konsep dan proses pemahaman dalam berbagai bentuk aktivitas belaajr (Rustan, Hanifah, \& Kanro, 2018). Aktivitas belajar sebagai aktivitas yang diberikan kepada pembelajar dalam situasi belajar mengajar. Media pembelajaran merupakan alat bantu yang dipergunakan guru untuk menyampaikan materi pelajaran kepada siswa (Oemar Hamalik 2009 : 179).

Media pembelajaran adalah suatu alat yang akan membantu kemudahan, kelancaran, serta keberhasilan proses belajar sebagaimana yang diharapkan Djahiri (dalam Ahmad Susanto, 2014 : 314). Bentuk alat komunikasi yang dapat digunakan untuk menyampaikan informasi dari sumber ke siswa secara terencana sehingga tercipta lingkungan belajar yang kondusif dimana penerimanya dapat melakukan proses belajar secara efisien dan efektif Menurut (Hamzah \& Nina Lamatenggo, 2011 : 122). Media adalah alat yang digunakan untuk menunjang suatu pembelajaran sehingga pembelajaran tersebut akan membantu siswa untuk lebih konsentrasi dalam prose belajar mengajar Menurut (Rusman, 2013 : 170).

Dampak positif dari adanya perkembangan IPTEK adalah tersedianya media yang dapat dipergunakan dalam kegiatan proses belajar mengajar yang selanjutnya kita kenal dengan nama media pembelajaran." Media adalah saluran informasi yang menghubungkan antara sumber informasi dan penerima (HM. Musfiqon, 2012 : 26). Kata media berasal dari bahasa latin medius yang secara harfiah berarti " tengah", perantara," atau pengantar". Dalam bahasa Arab medai adalah perantara atau pengantar pesan dari pengirim kepada penerima pesan Menurut (Azhar Arsyad, 2013 : 3). Menurut (Rusman 2013 :169) Media adalah pengantar pesan dari pengirim ke penerima pesan, dengan demikian media merupakan wahana penyalur informasi belajar atau penyalur pesan.

Media gambar adalah suatu penyajian secara visual yang menggunakan titik-titik, garis-garis, gambar-gambar, dan tulisan atau simbol visual untuk mengihtisarkan, menggambarkan, dan merangkum ide data atau kejadian Menurut (Daryanto, 2010 : 19). Manfaat gambar sebagai media pembelajaran diantaranya : 1 . Menimbulkan daya tarik pada diri siswa, 2. Mempermudah pengertian atau pemahaman siswa, 3. Memudahkan penjelasan yang sifatnya abstrak sehingga siswa lebih mudah memahami materi, 4. Memperjelas bagian-bagian yang paling penting, melalui gambar, kita dapat memperbesar bagian-bagian yang penting atau bagian yang kecil sehingga dapat diamati, 5 . Meningkat suatu uraian informasi yang dijelaskan dengan kata-kata mungkin 


\section{2 | Dahlia}

membutuhkan uraian panjang, uraian tersebut dapat ditunjukkan pada gambar (Subana dan Sunarti, 2009 : 322). Gambar foto yang baik sebagai media dalam pembelajaran adalah gambar yang sesuai dengan tujuan pembelajaran. Terdapat enam syarat yang perlu dipenuhi oleh gambar yang dijadikan sebagai media pembelajaran yaitu : 1.Autentik , 2. Sederhana, 3. Ukuran relatif, 4. Gambar harus mengandung gerak atau perbuatan, 5. Gambar harus sesuai dengan tujuan pembelajaran Menurut (Arief S. Sadiman 2010 : 33).

Media gambar sketsa merupakan cara efektif guna mempermudah dan lebih menyenangkan siswa dalam pembelajaran IPS. Sketsa adalah gambar yang sederhana yang belum jadi, atau draf kasar yang melukiskan bagianbagian pokoknya tanpa detail. Karena setiap orang normal dapat belajar menggambar, setiap guru yang baik haruslah dapat menuangkan ide-idenya ke dalam bentuk sketsa. Sketsa, selain dapat menarik perhatian murid, menghindari verbalisme dan dapat memperjelas penyampaian pesan, harganya pun tak perlu dipersoalkan sebab media ini dibuat langsung oleh guru. Sketsa dapat dibuat secara cepat sementara guru menerangkan d apat pula dipakai untuk tujuan tersebut (Arief S. Sadiman 2010 : 33). Hasil belajar adalah wujud perubahan tingkah laku dari segi kognitif. Hasil belajar kognitif berupa penguasaan materi pada saat proses pembelajaran di tunjukkan dengan penilaian tes kognitif. Hasil belajar siswa pada hakikatnya adalah perubahan tingkah laku sebagai hasil belajar dalam pengertian yang lebih luas mencakup bidang kognitif, afektif dan psikomotorik Menurut (Nana sudjana 2009 : 3).Kemampuan yang dimiliki siswa dapat dilihat dari segi kognitif . Kognitif dapat dilihat dari suatu perkembangan fungsi intelektual atau proses perkembangan kemampuan/kecerdasan otak anak (Muhibbin Syah 2010 : 59).

Mata pelajaran IPS materi yang bersifat kognitif dengan berupa pemahaman terhadap suatu objek. Pembelajaran IPS merupakan ilmu pengetahuan yang berkaitan dengan lingkungan sosial, cabang ilmu pengetahuan yang mempelajari tingkah laku manusia sebagai anggota masyarakat.tingkah laku manusia dalam masyarakat memiliki berbagai aspek seperti aspek ekonomi, aspek mental, aspek budaya, aspek hubungan sosial. Sub pokok pembahasan materi pada mata pelajaran IPS di kelas III yaitu tentang lingkungan alam dan buatan. Lingkungan alam adalah suatu lingkungan yang ada dengan sendirinya dan merupakan lingkungan yang diciptakan oleh Tuhan. Contohnya : gunung, danau, sungai, dan pantai. Sedangkan lingkungan buatan adalah lingkungan yang dibuat oleh manusia dan di dalamnya ada campur tangan manusia. Contohnya : rumah, jalan, sawah, dan gedung sekolah.

PiJIES: Pedagogik Journal of Islamic Elementary School 
Dalam proses belajar mengajar terutama pada mata pelajaran ilmu pengetahuan sosial, merupakan pengetahuan mengenai hubungan antara individu. Ilmu pengetahuan sosial menurut nasution "merupakan integrasi dari berbagai ilmu sosial seperti geografi, sejarah, ekonomi, antropologi, tata negara dan sejarah". Mata pelajaran IPS terkadang dianggap sebagai pelajaran keterampilan karna menyangkut berbagai hal yang dibutuhkan oleh seseorang sebagai warga masyarakat atau pun sebagai warga negara (Abdul Aziz Wahab 2008 : 38). IPS adalah ilmu pengetahuan yang mengkaji berbagai disiplin ilmu sosial dan humoniora serta kegiatan dasar manusia yang dikemas secara ilmiah dalam rangka memberi wawasan dan pemahaman yang mendalam kepada siswa, khususnya di tingkat dasar dan menengah menurut (Ahmad Susanto 2014 : 137 ). IPS wajib dipelajari di sekolah dasar. Hal ini dikuatkan dalam UU Sisdiknas pasal 37 bahwa mata pelajaran IPS merupakan muatan wajib yang harus ada dalam kurikulum pendidikan dasar menurut (Sapriyadi 2014 : 194-195).

Adapun tujuan mata pelajaran IPS di SD antara lain sebagai berikut : a. Mengenal konsep-konsep yang berkaitan dengan kehidupan masyarakat dan lingkungannya, b. Memiliki kemampuan dasar untuk berfikir logis dan kritis, rasa ingin tahu,inquiri, memecahkan masalah, dan keterampilan dalam kehidupan sosial, c. Memiliki komitmen dan kesadaran terhadap nilai-nilai sosial dan kemanusiaan, d.Memiliki kemampuan berkomunikasi, bekerja sama dan berkompetensi dalam masyarakat yang majemuk, ditingkat lokal nasional dan global. Tujuan utama pembelajaran IPS ialah untuk mengembangkan potensi siswa agar peka terhadap masalah sosial yang terjadi di masyarakat, memiliki sikap mental positif terhadap perbaikan segala ketimpangan yang terjadi, dan terampil mengatasi setiap masalah yang terjadi sehari-hari baik yang menimpa dirinya sendiri maupun yang menimpa masyarakat menurut (Ahmad Susanto 2014: 137).

\section{METODE}

Bagian ini meliputi: (1). Jenis penelitian dan pendekatan yang digunakan, (2). Populasi dan sampel (subjek penelitian/responden), (3). Instrumen dan teknik pengumpulan data, serta (4). Teknik analisis data yang digunakan.

Penelitian tindakan kelas menurut Suyanto yaitu suatu penelitian yang bersifat rekleftif dengan melakukan tindakan-tindakan tertentu untuk memperbaiki atau meningkatkan praktek-praktek pembelajaran di kelas secara profesional Menurut (Suyanto dalam Mahmud 2011 : 199). Subjek penelitian adalah siswa kelas III SDN 50 Bulu Datu Palopo, tahun pelajaran 2018/2019 semesterganjil yang berjumlah 23 orang ( 12 perempuan dan 11 lakilaki. Untuk mengumpulkan data dalam penelitian ini dilakukan dengan 


\section{4 | Dahlia}

observasi, tes , dan dokumentasi. Rumus yang digunakan untuk mencari hasil dari mean data tunggal yang seluruh skornya berfrekuensi satu adalah sebagai berikut : $\mathrm{Mx}=\frac{\sum X}{N} \mathrm{Mx}=$ Mean yang dicari, $\sum X=$ Jumlah seluruh nilai siswa, dan $\mathrm{N}=$ Jumlah siswa. (Untuk memperoleh frekuensi relatife (angka persen) dengan rumusan sebagai berikut: $P_{N}^{F} \times 100 \% \mathrm{~F}=$ Frekuensi yang sedang dicari persentasenya, $\mathrm{N}=$ Number Of Cases ( jumlah frekuensi/banyak individu),P = angka Persentase (Anas Sudijono 2010 : 81).

\section{PEMBAHASAN RUMUSAN MASALAH PERTAMA}

\section{Gambaran proses pelasanaan pembelajaran}

Perencanaan, pada tahap ini hal-hal yang dilakukan pada tahap perencanaan ini yaitu sebagai berikut: Menentukan materi yang akan diajarkan, Membuat Rencana Pelaksanaan Pembelajaran (RPP), Menyusun lembar observasi aktivitas siswa untuk melihat peningkatan hasil belajar siswa, Menyusun lembar observasi aktivitas guru untuk melihat perubahan belajar siswa, Menyusun tes evaluasi tentang materi yang telah diajarkan. Pelaksanaan Tindakan, tahap ini, kegiatan pembelajaran dilaksanakan sesuai dengan rencana pelaksanaan pembelajaran yang telah dipersiapkan sebelumnya. Kegiatan pembelajaran diawali dengan membaca do'a sebelum memulai kegiatan proses belajar mengajar,Guru melakukan langkah pembelajaran sesuai dengan skenario pembelajaran (rencana pembelajaran terlampir),Siswa mengikuti kegiatan pembelajaran dan melaksanakan kegiatan sesuai dengan skenario kegiatan belajar mengajar, Pengamat melakukan pengamatan sesuai dengan instrument pengamatan tentang aspek-aspek proses pembelajaran yang dilakukan guru dan aktivitas siswa dalam kegiatan pembelajaran.

Observasi, pada tahap ini untuk mengetahui proses pembelajaran yang dilakukan dan aktivitas siswa dalam kegiatan pembelajaran dengan menggunakan lembar observasi peneliti dan yang menjadi sasaran observasi peneliti yaitu aspek kognitif. Data hasil penelitian kognitif (pengamatan) dilakukan untuk siswa, dan indikator aspek proses pembelajaran yang dilakukan guru dalam kegiatan pembelajaran sesuai dengan instrumen pengamatan. Apsek-aspek proses pembelajaran yang dilakukan guru meliputi perencanaan, kegiatan utama, dan pemantapan, Refleksi : Tahap selanjutnya adalah mengadakan refleksi yaitu membahas dan mengevaluasi kegiatan pembelajaran yang baru saja dilaksanakan.

Refleksi dilakukan untuk mengetahui kekurangan atau kendala siklus I. Pelaksanaan pada siklus I dapat dikatakan cukup baik, namun masih ada beberapa kendala. Kendala yang dimaksud adalah: Siswa banyak yang kurang 
memahami materi tapi hanya diam dan tidak bertanya, siswa masih malumalu ketika diminta untuk menjelaskan materi yang telah diajarkan. Melihat kendala-kendala tersebut maka perlu dilakukan tindakan perbaikan agar hasil pembelajaran pada siklus II bisa lebih optimal. Kegiatan pembelajaran yang akan dilaksanakan pada siklus II penampilan mengajar guru akan ditingkatkan secara lebih baik dengan mengacu kepada kelemahan-kelemahan yang terjadi pada siklus I.

\section{Peningkatan hasil belajar IPS pada materi lingkungan alam dan buatan}

Deskripsi Pratindakan telah dikemukakan pada BAB pendahuluan bahwa hasil belajar siswa di kelas III SDN 50 Bulu' Datu tahun ajaran 2018/2019 tergolong rendah dikarenakan guru dalam kegiatan pembelajaran lebih banyak menggunakan metode ceramah, dan pemberian tugas sehingga siswa kurang bergairah dan merasa jenuh dalam proses pembelajaran. Proses pembelajaran IPS dilaksanakan dengan urutan sebagi berikut: pertama guru menjelaskan sedikit materi, kedua siswa disuruh membaca buku teks dan merangkum sementara guru sibuk melaksanakan kegiatan lain, yang antara lain mengerjakan administrasi, ketiga siswa disuruh mengerjakan soal-soal yang ada dalam kumpulan LKS, dan selanjutnya hasil pekerjaan dikumpulkan untuk dinilai.

Diketahui bahwa dari 23 siswa yang mengikuti tes pada prasiklus ternyata ada 2 siswa yang mendapat nilai termasuk kategori sangat baik, 4 siswa yang mendapat nilai termasuk kategori cukup, 17 siswa yang mendapa nilai termasuk kategori gagal, 0 siswa mendapat nilai termasuk kategori baik dan kurang. Selanjutnya Deskripsi Siklus I dilakasanakan selama 3 kali pertemuan, dengan 2 kali tatap muka dan 1 kali evaluasi dipertemuan akhir siklus. Hasil evaluasi siklus I sehinnga nilai rata-rata hasil belajar siswa kelas III SDN 50 Bulu' Datu diperoleh dengan rumus rata-rata: $\frac{1.660}{23}=72$, jadi nilai rata-rata siswa dengan menggunakan media gambar dalam pelajaran IPS diatas menunjukkan bahwa dari 23 siswa yang mengikuti tes evaluasi pada siklus I siswa yang mendapat nilai $\geq 70$ sebanyak 15 orang dan yang mendapat nilai dibawah KKM sebanyak 8 orang.

Deskripsi Siklus II dilaksanakan selama 3 kali pertemuan, dengan 2 kali tatap muka dan 1 kali evaluasi dipertemuan akhir siklus. Hasil evaluasi siklus II nilai rata-rata hasil belajar siswa SDN 50 Bulu' Datu diperoleh dengan rumus rata-rata $\frac{2120}{23}=92$, jadi nilai rata-rata siswa dengan menggunakan media gambar dalam pembelajaran IPS pokok di atas menunjukkan bahwa dari 23 siswa yang mengikuti tes evaluasi pada siklus II siswa yang mendapat nilai $\geq 70$ sebanyak 23 orang dan tidak ada yang mendapat di bawah nilai KKM. Hasil belajar siswa setelah diterapkan media gambar pada siklus II tidak ada siswa yang berada pada kategori gagal, tidak ada siswa yang berada pada 


\section{6 | Dahlia}

kategori kurang, tidak ada siswa yang berada pada kategori cukup, tidak ada siswa yang berada pada kategori baik, dan siswa yang berada pada kategori sangat baik sebanyak 23 orang.

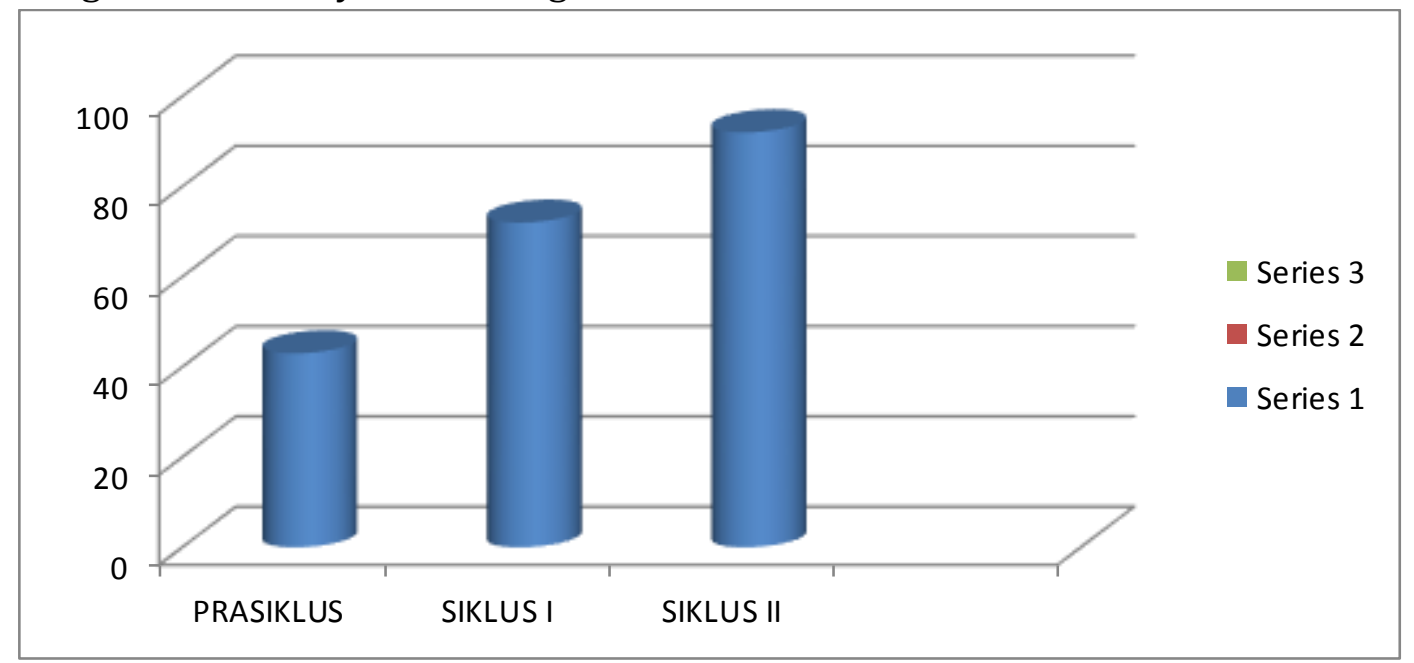

DiagramPra Siklus, Siklus I, Siklus II

Berdasarkan hasil tes siklus II menunjukan bahwa dari 23 siswa yang mengikuti tes hasil evaluasi, yang tuntas 23 siswa. Dengan demikian terjadi peningkatan yaitu dari 9\%, 65\% menjadi 100\%. Nilai rata-rata hasil belajar mengalami peningkatan dari 43, 72 menjadi 92. Hal ini menunjukkan adanya peningkatan pemahaman siswa terhadap materi pembelajaran.

\section{PEMBAHASAN PENELITIAN}

Dalam pembahasan ini diuraikan hasil penelitian mengenai peningkatan hasil belajar IPS melalui media gambar. Berdasarkan penelitian, penggunaan media gambar ternyata dapat meningkatkan hasil belajar IPS pada siswa kelas III SDN 50 Bulu' Datu Palopo. Hal ini di karenakan pembelajaran menggunakan media gambar dalam proses pembelajaran dapat menarik perhatian siswa sehingga membantu meningkatkan pemahaman siswa terhadap materi yang disampaikan guru. Dalam penggunaan media gambar, guru dapat menerapkan berbagai metode dan model-model pembelajaran yang menarik dalam penyampaian materi sehingga siswa tidak merasa jenuh dalam belajar. Guru bisa menggunakan model picture, examples, dan metode lain yang relevan dengan materi yang pelajaran. Media pembelajaran adalah segala bentuk alat komunikasi yang dapat digunakan untuk menyampaikan informasi dari sumber ke siswa secara terencana sehingga tercipta lingkungan belajar yang kondusif dimana penerimanya dapat melakukan proses belajar secara efisien dan efektif Hal ini sesuai dengan pendapat(Hamzah \& Nina Lamatenggo, 2011 : 122). Media pembelajaran merupakan suatu teknologi pembawa pesan yang dapat digunakan u ntuk kepe PiJIES: Pedagogik Journal of Islamic Elementary School 
rluan pembelajaran. Media pembelajaran merupakan sarana komunikasi dalam bentuk cetak maupun pandang dan dengar termasuk perangkat keras Menurut ( Rusman, $2013: 170$ ).

Hasil belajar siswa digunakan untuk mengetahui sejauh mana pemahaman siswa terhadap materi pembelajaran yang dinyatakan dalam bentuk nilai. Menyatakan bahwa hasil belajar dapat diartikan sebagai tingkat keberhasilan siswa dalam mempelajari materi pelajaran di sekolah yang dinyatakan dalam skor yang diperoleh darihasil tes mengenal sejumlah materi pelajaran tertentu Menurut Nawawi (dalam kutipan Ahmad Susanto 2014: 5 ). Hasil belajar adalah perubahan perilaku yang relatif menetap dalam diri seseorang sebagai akibat dari interaksi seseorang dengan lingkungannya. Hasil belajar memiliki beberapa ranah atau kategori dan secara umum merujuk kepada aspek pengetahuan, sikap, dan keterampilan (Hamzah B Uno, 2012: 213).

Berdasarkan presentase ketuntasan hasil belajar siswa kelas III SDN 50 Bulu' Datu setelah menggunakan media pembelajaran yaitu media gambar pada pembelajaran IPS, dapat dilihat bahwa banyaknya siswa yang tuntas pada siklus I sebanyak 15 siswa atau 65\% dan banyaknya siswa yang tidak tuntas sebanyak 8 siswa atau 35\%, sedangkan siswa yang tuntas pada siklus II sebanyak 23 siswa sekitar 100\%. Berdasarkan hasil tes siklus II menunjukan bahwa dari 23 siswa yang mengikuti tes hasil evaluasi, yang tuntas 23 siswa. Dengan demikian terjadi peningkatan yaitu dar i 9\%, 65\% menjadi 100\%. Nilai rata-rata hasil belajar peningkatan pemahaman siswa terhadap materi pembelajaran.

\section{PENUTUP}

Pada bagian ini menyajikan ringkasan dari uraian mengenai hasil dan pembahasan, mengacu pada tujuan penelitian. Berdasarkan kedua hal tersebut dikembangkan pokok-pokok pikiran baru yang merupakan esensi dari temuan penelitian.

Selanjutnya dikemukakan saran. Saran disusun berdasarkan temuan penelitian yang telah dibahas. Saran dapat mengacu pada tindakan praktis, pengembangan teori baru, dan/atau penelitian lanjutan

Berdasarkan hasil penelitian dan pembahasan maka dapat disimpulkan bahwa: Penggunaan media gambar dalam meningkatkan hasil belajar siswa kelas III SDN 50 Bulu' Datu pada mata pelajaran IPS. Hal ini dapat terlihat dari perolehan skor rata-rata hasil belajar siswa pada siklus I yaitu 72 sedangkan perolehan skor hasil belajar siswa pada siklus II yaitu 92 dapat dikategorikan hasil belajar siswa meningkat. Media pembelajaran sangat membantu dalam peningkatan hasil belajar siswa. Penggunaan alat media gambar merupakan 
salah satu dari media pendidikan untuk membantu proses belajar mengajar agar proses komunikasi dapat berhasil dengan baik dan efektif.

\section{DAFTAR PUSTAKA}

Arsyad Azhar. 2013. Media Pembelajaran, Jakarta: Raja Grafindo Persada

Bambang \& Warsita. 2008. Teknologi Pembelajaran Landasan dan Aplikasinya Jakarta : Rineka Cipta

Daryanto. 2010. Media Pembelajaran Yogyakarta : Gava Media

Hamalik Oemar. 2009. Psikologi Belajar \& Mengajar Bandung, Sinar Baru Harapan

Hamzah \& Nina Lamatenggo. 2011. Teknologi Komunikasi \& Informasi Pembelajaran Jakarta : Bumi Aksara

Hujair AH. Sanaky. 2009. Media Pembelajaran Yogyakarta : Safiria Insania Press

Ihsan Fuad. 2005. Dasar - Dasar Kependidikan Jakarta : Rineka Cipta.

Mahmud. 2011. Metode Penelitian Pendidikan Bandung : Pustaka Setia

Rusman. 2013. Pembelajaran Berbasis Teknologi Informasi dan Komunikasi, Jakarta : Raja Grafindo Persada

Rustan, E. (2001). Budaya Leluhur dalam Memperkukuh Tatanan Masyarakat di Era Globalisasi. In Seminar Internasional Pemertahanan Identitas Masyarakat Multikultural di Era Globalisasi (pp. 79-86). Surabaya.

Rustan, E., Hanifah, N., \& Kanro, B. (2018). De-radicalization in the Implementation of Islamic Education Curriculum in SMA Masamba South Sulawesi. Dinamika Ilmu, 18(2), 271-283. https://doi.org//10.21093/di.v18i2.1338

Sadiman Arief S. 2012. Media Pendidikan Depok:Rajagrafindo Persada 2010. Media Pendidkan, Pengertian, Pengembangan, an Pemanfaatan Jakarta : Rajawali Pers

Sagala Syaiful. 2008. Konsep dan Makna Pembelajaran Untuk Membantu Memecahkan Problematika Belajar dan Mengajar Bandung : Alfabeta,

Sapriyadi. 2014. Pendidikan IPS Konsep dan Pembelajaran Bandung : Remaja Rosdakarya

Slameto. 2015. Belajar dan Faktor-Faktor yang Mempengaruhinya Jakarta : Rineka Cipta

Subana dan Sunarti. 2009. Strategi Belajar Mengajar Bahasa Indonesia Bandung : Pustaka Setia

Sudarwan Danim. 2011. Pengantar Kependidikan Landasan Teori, dan 234 Metafora Pendidikan, Bandung : Alfabeta 
Sudijono Anas. 2010. Pengantar Statisti Pendidikan, Jakarta : PT Raja Grapindo Persada

Sukmadinata Nana Syaodih. 2009. Landasan Psikologi Proses Pendidikan Bandung : Remaja Rosdakarya

Sukmadinata. 2009. Landasan Psikologi Proses Pendidikan Bandung : Remaja Rosda Karya

Susanto Ahmad. 2014. Pengembangan Pembelajaran IPS Jakarta, Prenada Media Group

Syah Muhibbin. 2010. Psikologi Pendidikan Bandung : Remaja Rosdakarya Hamzah B Uno. 2012. Model Pembelajaran, Jakarta: Remaja Rosdakarya

Wahab Abdul Aziz. 2008. Metode dan Model-Model Mengajar IPS Bandung : Alfabeta 
40 | Dahlia

----Halaman Ini Sengaja Dikosongkan----

PiJIES: Pedagogik Journal of Islamic Elementary School 